\title{
Screening of Anticancer Materials from Myxobacteria and Evaluation of Their Bioactivity in Vivo
}

\author{
Jia Hong \\ Key Lab of Microbial Diversity Research and Application of Hebei Province \\ College of Life Sciences, Hebei University \\ Baoding 071002, Hebei Province, China \\ Zhang Liping (Corresponding Author) \\ Key Lab of Microbial Diversity Research and Application of Hebei Province \\ College of Life Sciences, Hebei University \\ Baoding 071002, Hebei Province, China
}

Received: January 1, 2011 Accepted: January 17, 2011 doi:10.5539/ijb.v3n2p168

This research was financially supported by Hebei Province Research Project titled "Hebei microbial resource base information database" (Grant No. 10967146D).

\begin{abstract}
Myxobacteria are a class of prokaryotes with complex multi-cellular behavior and could produce various bioactive materials. Forty-eight strains stored in Key Lab of Microbial Diversity Research and Application of Hebei Province were screened by MTT methods with L1210, Hela and normal diploid human embryonic lung fibroblast cell lines as screening models. The results demonstrated that most of the strains could inhibit cancer cells. The inhibition rates to L1210 and Hela are about 78.5\% and 59\%, respectively. Strain 910018 and 920036 showed higher inhibition activity to cancer cells L1210 and Hela in compare with lower inhibition activity to normal diploid human embryonic lung fibroblast cell line. Therefore, the extracts from the two strains have the potentials as anticancer drugs and were undertaken in vivo anticancer experiments. The results showed that strain 910018 and 920036 could inhibit mice transplanted liver cancer cells H22. The inhibition rate of low doses group of strain 910018 is $69.37 \%$ and that of strain 920036 is $54.98 \%$. Therefore, the two strains could be good candidates for producing of anticancer drugs.
\end{abstract}

Keywords: Myxobacteria, MTT, Cancer inhibition rate, L1210, Hela

\section{Introduction}

Myxobacteria are a class of Gram-negative prokaryotes with complex multi-cellular behavior and morphology (Fang \& Zhang, 2001). According to the phylogenetic analysis based on 16S rDNA sequences, Myxobacteria belong to $\delta$ - subclass of Proteobacteria (Iizuka et al., 2003). In the second edition of "Bergey's Manual of Systematic Bacteriology", Myxobacteria are classified as Myxococcales of Deltaproteobacteria of Proteobacter and include 3 orders, 6 families, 19 genus and 62 species (George et al., 2004).

More than 400 bioactivity materials were reported from Myxobacteria, took up about 3\% of the total bioactivity materials from microbes, just after Actinomycetes and Bacillusc. Many studies reported that the secondary metabolites of Myxobacteria have great potentials for application (Guo, 2007; Guo et al., 2007). There were about 80 species of basic structures and about 450 species of analogous compounds in secondary metabolites of Myxobacteria. Only a few of them were reported in other microbes. Most compounds isolated form Myxobacteria were with novel structure and part of them were with pharmacologic and biologic activity. Therefore, Myxobacteria were a group of microbe resources that need to be further studied. However, the study was blocked as culture difficulties of Myxobacteria. In order to research new medicine, more attention should be paid to secondary metabolites of Myxobacteria. 


\section{Materials and Methods}

\subsection{Materials}

\subsubsection{Strains}

The 48 Myxobacteria strains used in this study were isolated and stored by Key Lab of Microbial Diversity Research and Application of Hebei Province.

2.1.2 Seed medium

CAS medium: $1 \%$ Casein, $0.1 \% \mathrm{MgSO}_{4} \cdot 7 \mathrm{H}_{2} \mathrm{O}$, adjust to $\mathrm{pH}$ 7.2.

2.1.3 Fermentation medium

VY/2 medium: $1 \%$ Yeast powder, $0.1 \% \mathrm{CaCl}_{2} \cdot 2 \mathrm{H}_{2} \mathrm{O}, 0.5 \mathrm{mg} / \mathrm{mL} \mathrm{VB}_{12}$, adjust to $\mathrm{pH} 7.2$.

\subsubsection{Cell medium}

$10 \%$ bovine serum, $90 \%$ RPMI 1640

\subsubsection{Cell lines}

L1210, Hela and MRC-5 were murine leukemia cell lines, human cervical cancer cell lines and Normal diploid human embryonic lung fibroblasts, respectively. L1210 and MRC-5 were supplied by Animal Experimental Center of Hebei Medical University. Hela was supplied by Microbiology lab of Hebei Medical University.

\subsubsection{Experimental animals}

Adult and healthy Kunming mice were purchased from Experimental Animal Center of Hebei Medical University. The qualification number is No. 04088. The numbers of male and female mice were half-half. The average weight is about $20 \pm 2 \mathrm{~g}$.

\subsubsection{Extraction of fermentation products}

The Myxobacteria cultures were mixed with same volume of ethanol and incubated overnight. Then the leaching liquor was concentrated with rotary evaporator and the concentrated solution was lyophilized at $-50{ }^{\circ} \mathrm{C}$.

\subsection{Methods}

\subsubsection{Fermentation of Myxobacteria}

Purified strains were remained in VY/2 medium and inoculated to CAS seed medium, shaking with $200 \mathrm{rpm} / \mathrm{min}$ for 4 days at $28{ }^{\circ} \mathrm{C}$. Then the seed solution was inoculated to fermentation medium VY/2 with ratio of $10 \%$, shacking with $200 \mathrm{r} / \mathrm{min}$ for 7 days at $28^{\circ} \mathrm{C}$.

\subsubsection{Screening of anticancer extract form Myxobacteria in vitro by MTT}

\subsubsection{Preparation of sample solution}

Two hundred $\mathrm{ml}$ Myxobacteria cultures were extracted by ethanol, concentrated, lyophilized and weighted. Then $4 \mathrm{ml}$ RPMI-1640 medium was used to dissolve the dry sample. The samples were marked with No.

\subsubsection{MTT experiment}

The experiment included 4 dose groups $(3.33 \mathrm{mg} / \mathrm{ml}, 6.65 \mathrm{mg} / \mathrm{ml}, 13.3 \mathrm{mg} / \mathrm{ml}, 26.6 \mathrm{mg} / \mathrm{ml})$ and the culture with same cell density was used as blank control. Solvent control was zero adjustment. $0.1 \mathrm{ml}$ volumes of $10^{5} \mathrm{cfu} / \mathrm{ml}$ cell cultures were added to each well of 96-well plate and the plate was incubated for $12 \mathrm{~h}$. Then, $20 \mu \mathrm{l}$ sample solution was added to each well with triplicate and incubated for $48 \mathrm{~h}$ at $37{ }^{\circ} \mathrm{C}$ with $5 \% \mathrm{CO}_{2}$ saturation. $20 \mu \mathrm{l}$ MTT was added to each well and incubated for $4 \mathrm{~h}$, centrifuged for $10 \mathrm{~min}$ with $2000 \mathrm{rpm} / \mathrm{min}$. Then the supernatant was discarded (should be careful, remain the Formazan particles). $150 \mu$ l DMSO was added to each well with shaking for 5-10 min until blue particles were soluble completely and the solution color became dark blue. The $\mathrm{OD}_{570 \mathrm{~nm}}$ was measured immediately and the inhibition rate (IR) of cancer cell proliferation was calculated $(\mathrm{Li}, 2004)$. Then half inhibitory concentration $\left(\mathrm{IC}_{50}\right)$ was calculated by modified Karber method $(\mathrm{Mu}$, 2007).

$$
\begin{gathered}
\text { IR }(\%)=\left(1-\mathrm{OD}_{570 \mathrm{~nm}} \text { of experiment group/ } \mathrm{OD}_{570 \mathrm{~nm}} \text { of negative control }\right) \times 100 \% \\
\mathrm{IC}_{50}=\lg ^{-1}\left[\mathrm{Xm}-\mathrm{I} \times\left(\mathrm{P}-\frac{3-\mathrm{Pm}-\mathrm{Pn}}{4}\right)\right]
\end{gathered}
$$

Xm: logarithm of maximum dose; I: difference of the two adjacent logarithmic dose; P: sum of positive reaction 
rate; Pm: maximum inhibition rate; Pn: minimum inhibition rate.

\subsubsection{Data statistical analysis}

The experiment was carried out with six groups and 3 replicates. Data were analyzed by SPSS16.0, using ANOVA and t-test. Test level $\alpha=0.05$ and $\mathrm{P}<0.05$ means significant difference.

\subsubsection{Cancer cell inhibition experiment in vivo}

\subsubsection{Preparation of sample solution}

Five hundred ml of strain 910018 and 920036 cultures were extracted by ethanol, concentrated, lyophilized and weighted. The No. 7 sample (extracted from strain 910018) is about $1.8 \mathrm{~g}$ and diluted with saline solution to 40 $\mathrm{mg} / \mathrm{ml}$ and $32.7 \mathrm{mg} / \mathrm{ml}$. The No. 20 sample (extracted from strain 920036) is about $1.6 \mathrm{~g}$ and diluted with saline solution to $45.7 \mathrm{mg} / \mathrm{ml}$ and $35.5 \mathrm{mg} / \mathrm{ml}$.

\subsubsection{Evaluation of experimental doses in vivo}

Six mice were in a group. The mice were i.p. injected with $0.2 \mathrm{ml}$ volumes of extracts samples and maintained for 7 days to record the toxic reaction and mortalities. Mice in control group were i.p. injected with same volumes of saline solution. $1 / 30 \sim 1 / 50$ of the above concentration was used to test $\mathrm{LD}_{50}$.

\subsubsection{Evaluation of samples toxicity}

Six mice were in a group. The mice were i.p. injected with low- and high- concentration of samples and maintained for 7 days to record the mental, appetite and so on, then compared with mice in control group which were i.p. injected with same volumes of saline solution.

\subsubsection{Effect of No. 7 and 20 samples on mice transplanted liver cancer cells H22}

The experiment was carried out with 6 groups and 12 mice in one group. The differences of mice weight were less than $4 \mathrm{~g}$. The male and female mice were half-half and breed separately. Two of the 6 groups were as positive control and negative control, respectively. The other 4 groups were low- and high-concentration groups of strain 910018 and 920036 , respectively. The cyclophosphamide solution $(5 \mathrm{mg} / \mathrm{ml})$ stored at $4{ }^{\circ} \mathrm{C}$ was used as positive control and saline solution was used as negative control.

Ascites (milky white, thickness) was sampled aseptically from tumor bearing mouse after injection of 7-10 days. The ascites was diluted to $2 \times 10^{7}$ cancer cells / $\mathrm{ml}$ with sterile saline solution. The mice in experimental groups were injected with $0.2 \mathrm{ml}$ volumes of cancer cells suspensions to made tumor-bearing mouse model. From the second to tenth days of injection, $0.2 \mathrm{ml}$ volumes of samples were i.p. injected to each mouse per day. Positive control group was injected with same volumes of $5 \mathrm{mg} / \mathrm{ml}$ cyclophosphamide solution from the fifth to tenth day. Negative control group was injected with saline solution for ten days. The changes of behavior, fur cover, mental state, mouth, nasal cavity, auditory meatus, anus, reproductive organs and excrement, development of cancer and mice mortalities were recorded. At the eleventh day after injection, 6 mice from each group (male: female $=3: 3$ ) were weighted and sacrificed by take out of the vertebral. Tumor organization, spleen and thymus was peeled, weighted. The tumor weight/body weight, spleen weight/body weight, thymus weight/body weight and cancer inhibition rate were calculated. For the rest mice, the survival time was recorded and the life elongation rate was calculated. The experiment was repeated 3 times. Data were analyzed by SPSS16.0, using ANOVA and t-test.

Cancer Inhibition Rate $=(1-$ Tumor weight of experiment group/ Tumor weight of control group $) \times 100 \%$

Life Elongation Rate $=($ Average survival days of experiment group $/$ Average survival days of control group -1$)$ $\mathrm{x} 100 \%$

\section{Results and discussion}

\subsection{MTT results}

\subsubsection{In vitro effect of extracts on L1210 and Hela}

Forty-eight Myxobacteria strains isolated and stored by Key Lab of Microbial Diversity Research and Application of Hebei Province were fermented and extracted. Anticancer materials were screened by MTT method using 96-well plate, with L1210, Hela and MRC-5 cell lines as screening models. The results were showed in Table 1.

Most of the 48 samples could inhibit growth of L1210 and Hela cells. L1210 cells were more sensitive to the extracts than Hela cells. The inhibition activities at dose of $26.6 \mathrm{mg} / \mathrm{mL}$ of 7 strains to L1210 and Hela cells are more than $\mathrm{IC}_{50}$ of $85 \%$ strains (Table 2 ).

The results demonstrated that the secondary metabolite of the 48 Myxobacteria strains could widely inhibit 
growth of cancer cells. The $\mathrm{IC}_{50}$ of $78.5 \%$ of strains to $\mathrm{L} 1210$ amounts to the bioactive materials in $2 \sim 8 \mathrm{ml}$ original fermentation broth. The $\mathrm{IC}_{50}$ of $59 \%$ of strains to Hela amounts to this value. The inhibition rates of most strain to L1210 were usually higher than that to Hela at the same doses. This demonstrated that L1210 was more sensitive and the inhibition activity of a sample was different to different cancer cells.

\subsubsection{Effect of extracts with different concentration on relative survival of MRC-5}

A good anticancer drug not only could kill cancer cell powerfully, but also minimize the damage to normal cells. Therefore, the sample should be screened by the Normal diploid cells. Fifteen out of 19 strains could inhibit growth of MRC-5 at dose of $20 \mu \mathrm{l} /$ well. No. 7, 20, 5, and 1 samples affected growth of MRC-5 least. The cells remain normal shape and transparent. In addition, No. 7 (extracted from strain 910018) and 20 (extracted from strain 920036) smples could inhibit growth of both L1210 and Hela cells powerfully.

\subsection{In vivo experiment}

\subsubsection{Evaluation of experimental doses in vivo}

According to the acute toxicity experiment, the low- and high-concentration for No. 7 sample were $40 \mathrm{mg} / \mathrm{ml}$ and $32.7 \mathrm{mg} / \mathrm{ml}$, respectively. the low- and high-concentration for No. 20 sample were $45.7 \mathrm{mg} / \mathrm{ml}$ and 35.5 $\mathrm{mg} / \mathrm{ml}$, respectively.

\subsubsection{Evaluation of samples toxicity}

Thirty mice were divided in 5 groups. Mice were continuously injected with $40 \mathrm{mg} / \mathrm{ml}$ and $32.7 \mathrm{mg} / \mathrm{ml}$ of No. 7 sample and $45.7 \mathrm{mg} / \mathrm{ml}$ and $35.5 \mathrm{mg} / \mathrm{ml}$ of No. 20 sample respectively for 7 days. The injected mice demonstrated normal growth, thick fur, normal mobility, normal nasal cavity, auditory meatus, anus and reproductive organs. No significant differences between body weights of experimental group and control group. This means that the low-concentration samples did not have obvious toxicity.

\subsubsection{Effect of No. 7 and 20 samples on mice transplanted liver cancer cells H22}

No. 7 and 20 samples could inhibite mice transplanted liver cancer cells H22 significantly. No. 7 sample showed higher inhibition rate than No. 20 sample and showed better at low-concentration level (Table 3).

\subsubsection{Effect of No. 7 and 20 samples on survival of tumor bearing mouse}

Life elongation rate is another important indicator for evaluation of anticancer drugs. No. 7 and 20 samples could prolong survial time of tumor bearing mouse significantly. The result showed that the effect of No. 7 sample on survival time elongation was better than No. 20 sample (Table 4).

\subsubsection{Effect of No. 7 and 20 samples on mice immunity}

Thymus and liver are important immune organs. Thymus is responsible for cell-mediated immunity and liver is responsible for humoral-mediated immunity. Regulator of immune organs often increases the weight of immune organs. So the immunity status could be indicated by the thymus index and spleen index, which were ratios of thymus and spleen weight to body weight, respectively.

\section{Spleen index $=$ Spleen weight $/$ Body weight $\quad$ Thymus index $=$ Thymus weight $/$ Body weight}

The results demonstrated that No. 7 and 20 samples could not increase mice immunity (Table 5). Therefore, cancer inhibition activity of No. 7 and 20 samples was not achieved by mice immunity increase.

\section{Conclusion}

In the present study, 48 strains isolated and stored by Key Lab of Microbial Diversity Research and Application of Hebei Province were fermented, extracted, concentrated and lyophilized. The samples were screened by MTT method with 3 cancer cell lines as models. Two strains (910018 and 920036), that could inhibit cancer cells but less or not inhibit normal diploid human embryonic lung fibroblasts, were screened. The both strains were proved to inhibit mice transplanted liver cancer cells $\mathrm{H} 22$ and to prolong survival time of mice. Through statistic analysis of mice body weight, spleen weight/body weight and thymus weight/body weight, it was concluded that cancer inhibition activity of the two samples was not achieved by mice immunity increase and decrease mice body weight. Within the safe dose, anticancer activity of low-concentration group was better than that of high-concentration group and low-concentration group also showed lower toxicity. Strains 910018 and 920036 could be as candidates of anticancer drugs. However, the function mechanisms still remained to study.

\section{References}

Fang,X.M. \& Zhang, L.P. (2001). A preliminary study on ecological diversity of myxobacteria. Biodiversity Science, 9(3), 207- 213. 
George, M., Garrity, Julia, A.B. \& Timothy, G.L. (2004). Taxonomic Outline of the Prokaryotes Bergey's Manual of Systematic Bacteriology. 2nd ed. New York: Springer-Verlag, pp134- 137.

Guo, W.J. (2007). Screening of myxobacteria and new antitumor antibiotic produced by myxobacteria. Wuxi, Jiangnan University.

Guo, W.J., Zhu, Q.J. \& Tao, W.Y. (2007). Selection of Polyangium vitellinum JSW103 (Myxobacteria)with High Active Anti-tumor Materials. Guizhou Agricultural Sciences, 35 (2), 5-8.

Iizuka, T., Jojima, Y. \& Fudou R et al.(2003). Enhygromyxa salina gen. nov.,sp. Nov., a slightly halophilic myxobacterium isolated from the coastal areas of Japan. System Appl Microbiol, 6, 189-196.

Li, N. (2004). Preliminary study of screening and function mechanisms anticancer of bioactive materials from myxobacteria. Baoding, Hebei University.

Table 1. In vitro inhibition effect of ethanol extract from 48 Myxobacteria strains on L1210 and Hela cell lines

\begin{tabular}{|c|c|c|c|c|}
\hline \multirow{3}{*}{ Cell lines } & \multirow{2}{*}{ doses } & \multicolumn{3}{|c|}{ Number of strains with different inhibition rate } \\
\cline { 3 - 5 } & & $>30 \%$ & $>60 \%$ & $>90 \%$ \\
\hline \multirow{4}{*}{ L1210 } & $3.33 \mathrm{mg} / \mathrm{mL}$ & 4 & 0 & 0 \\
\cline { 2 - 5 } & $6.65 \mathrm{mg} / \mathrm{mL}$ & 13 & 0 & 0 \\
\cline { 2 - 5 } & $13.3 \mathrm{mg} / \mathrm{mL}$ & 30 & 14 & 0 \\
\cline { 2 - 5 } & $26.6 \mathrm{mg} / \mathrm{mL}$ & 43 & 36 & 6 \\
\hline \multirow{3}{*}{ Hela } & $3.33 \mathrm{mg} / \mathrm{mL}$ & 0 & 0 & 0 \\
\cline { 2 - 5 } & $6.65 \mathrm{mg} / \mathrm{mL}$ & 7 & 0 & 0 \\
\cline { 2 - 5 } & $13.3 \mathrm{mg} / \mathrm{mL}$ & 12 & 5 & 4 \\
\cline { 2 - 5 } & $26.6 \mathrm{mg} / \mathrm{mL}$ & 33 & 13 & 0 \\
\hline
\end{tabular}

Table 2. In vitro $\mathrm{IC}_{50}(\mathrm{mg} / \mathrm{mL})$ to $\mathrm{L} 1210$ and Hela cell lines of extracts from 7 Myxobacteria strains

\begin{tabular}{|c|c|c|c|c|c|c|c|}
\hline \multirow{2}{*}{ Cell lines } & \multicolumn{7}{|c|}{$\mathrm{IC}_{50}(\mathrm{mg} / \mathrm{mL})$ of different strains } \\
\cline { 2 - 8 } & $6 \#$ & $7 \#$ & $9 \#$ & $16 \#$ & $17 \#$ & $18 \#$ & $20 \#$ \\
\hline L1210 & 10.98 & 9.46 & 6.10 & 6.42 & 7.88 & 6.83 & 7.99 \\
\hline Hela & 11.35 & 9.47 & 16.99 & 7.34 & 8.34 & 11.60 & 8.41 \\
\hline
\end{tabular}

Table 3. Effect of No. 7 and 20 samples on mice transplanted liver cancer cells $H 22$ ( $\mathrm{x} \pm \mathrm{s}, \mathrm{n}=6$ )

\begin{tabular}{|l|c|c|c|c|}
\hline \multicolumn{1}{|c|}{ Group } & No. of animal & Weight of tumor $(\mathrm{g})$ & Cancer inhibition rate (\%) & $\mathrm{P}$ \\
\hline No. 7 high-concentration & 6 & $1.80 \pm 0.08$ & 33.58 & $\mathrm{P}>0.05$ \\
\hline No. 7 low-concentration & 6 & $0.83 \pm 0.08$ & 69.37 & $\mathrm{P}<0.01$ \\
\hline No. 20 high-concentration & 6 & $1.76 \pm 0.14$ & 35.06 & $\mathrm{P}<0.05$ \\
\hline No. 20 low-concentration & 6 & $1.22 \pm 0.23$ & 54.98 & $\mathrm{P}<0.01$ \\
\hline Positive control & 6 & $0.58 \pm 0.06$ & 78.60 & $\mathrm{P}<0.01$ \\
\hline Negative control & 6 & $2.71 \pm 0.42$ & & \\
\hline
\end{tabular}

P: Compared with negative control 
Table 4. Effect of No. 7 and 20 samples on survival of tumor bearing mouse

\begin{tabular}{|l|c|c|c|}
\hline \multicolumn{1}{|c|}{ Group } & Survival time (d) & Life elongation rate & $\mathrm{P}$ \\
\hline Negative control & $18.33 \pm 2.50$ & & \\
\hline Positive control & $31.45 \pm 3.52$ & 71.57 & $\mathrm{P}<0.01$ \\
\hline No. 7 high-concentration & $33.17 \pm 3.82$ & 80.96 & $\mathrm{P}<0.01$ \\
\hline No. 7 low-concentration & $41.50 \pm 4.32$ & 126.40 & $\mathrm{P}<0.01$ \\
\hline No. 20 high-concentration & $29.83 \pm 4.02$ & 62.74 & $\mathrm{P}<0.01$ \\
\hline
\end{tabular}

Table 5. Effect of No. 7 and 20 samples on ratio of mice organ weight/body weight $(x \pm s, n=6)$

\begin{tabular}{|c|c|c|c|c|}
\hline Group & Liver index $(\mathrm{mg} / \mathrm{g})$ & $\mathrm{P}$ & Thymus index $(\mathrm{mg} / \mathrm{g})$ & $\mathrm{P}$ \\
\hline No. 7 high-concentration & $13.87 \pm 1.59$ & $\mathrm{P}>0.05$ & $3.06 \pm 1.55$ & $\mathrm{P}>0.05$ \\
\hline No. 7 low-concentration & $13.49 \pm 4.55$ & $\mathrm{P}>0.05$ & $3.25 \pm 1.05$ & $\mathrm{P}>0.05$ \\
\hline No. 20 high-concentration & $14.05 \pm 4.45$ & $\mathrm{P}>0.05$ & $3.13 \pm 1.33$ & $\mathrm{P}>0.05$ \\
\hline No. 20 low-concentration & $17.22 \pm 3.99$ & $\mathrm{P}>0.05$ & $3.14 \pm 1.21$ & $\mathrm{P}>0.05$ \\
\hline Positive control & $7.01 \pm 0.57$ & $\mathrm{P}<0.05$ & $0.78 \pm 0.68$ & $\mathrm{P}<0.05$ \\
\hline Negative control & $12.71 \pm 2.28$ & $2.76 \pm 1.17$ & & \\
\hline
\end{tabular}

P: Compared with negative control 